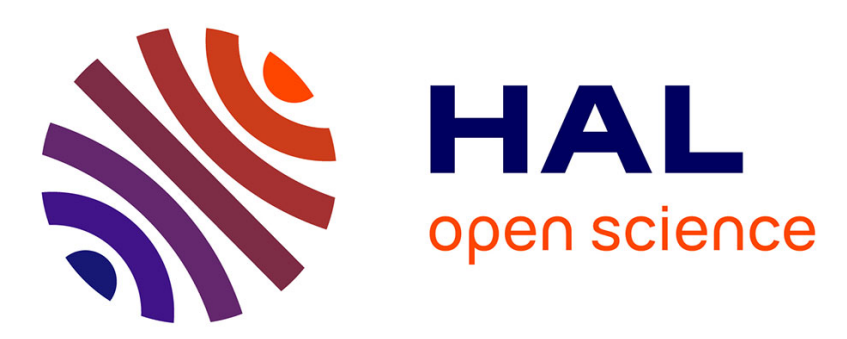

\title{
A real world project driven approach, a pilot experience in a graduate enterprise programme: ten years on \\ Nathalie Schieb-Bienfait
}

\section{To cite this version:}

Nathalie Schieb-Bienfait. A real world project driven approach, a pilot experience in a graduate enterprise programme: ten years on. International Journal of Entrepreneurship and Small Business, 2004, 1, pp.176 - 191. 10.1504/IJESB.2004.005383 . hal-01385010

\author{
HAL Id: hal-01385010 \\ https://hal.science/hal-01385010
}

Submitted on 14 Dec 2016

HAL is a multi-disciplinary open access archive for the deposit and dissemination of scientific research documents, whether they are published or not. The documents may come from teaching and research institutions in France or abroad, or from public or private research centers.
L'archive ouverte pluridisciplinaire HAL, est destinée au dépôt et à la diffusion de documents scientifiques de niveau recherche, publiés ou non, émanant des établissements d'enseignement et de recherche français ou étrangers, des laboratoires publics ou privés. 


\title{
A real world project driven approach, a pilot experience in a graduate enterprise programme: ten years on
}

\author{
Nathalie Schieb-Bienfait \\ IAE (Business Administration Institute), \\ University of Nantes, France \\ E-mail: schieb-bienfait@iae.univ-nantes.fr
}

\begin{abstract}
In the search for more and better ways of nurturing enterprising people and especially for developing entrepreneurs, the role of education and training is seen as absolutely essential. After reviewing major key research issues about entrepreneurship education and training implementation, we present a specific initiative built on the introduction of a new venture creation programme in higher education. Such an experimental programme allows the implementation of a cross-disciplinary area of training, which drives students to adopt an integrative and holistic approach for business venture creation and development.
\end{abstract}

Keywords: graduate enterprise programme; France; entrepreneurship development.

Reference to this paper should be made as follows: Schieb-Bienfait, N. (2004) 'A real world project driven approach, a pilot experience in a graduate enterprise programme: ten years on', Int. J. Entrepreneurship and Small Business, Vol. 1, Nos. 1/2, pp.176-191.

Biographical notes: Nathalie Schieb-Bienfait is an Associate Professor of Small Enterprise Management and Entrepreneurship at the IAE (Business Administration Institute), co-founder and responsible for the Centre for Entrepreneurship - Creactiv -, University of Nantes (France) Her research interests are focused on the process of new firm creation, entrepreneurial strategies, small business strategy and entrepreneurship education. She has published papers in this area (Revue Internationale PME, Gestion 2000 ...). Her research has appeared as chapters in edited books on entrepreneurship and strategy.

\section{Introduction}

In the search for more and better ways of nurturing enterprising people and especially for developing entrepreneurs, the role of education and training is seen as absolutely essential. Three key avenues can be considered: education about enterprise, education through enterprise, and education for enterprise (Scott, Rosa and Klandt 1994). In the second perspective, this paper relates the results of an education process experience which can be enhanced using new pedagogical disposals: it makes use of 'enterprising' situations, including student centred and a real world project driven approach. 


\section{New venture creation education: a brief review of the literature}

We start off by assessing major issues that deal with the design and implementation of entrepreneurship programme. This first part is dedicated to a study of the literature on education and entrepreneurship, particularly the role of education in the stimulation of entrepreneurship. It uses a framework based on several key issues: why teach entrepreneurship? For whom? Who should do it? What teaching/learning models and objectives? How can it be evaluated? (Figure 1) These questions which are subject to influences by education models are put forward. This discussion will be of help in the presentation of our case study and its critical analysis.

In fact, the implementation of a new venture creation programme is implicitly based on choices and decisions pertaining to either the field of entrepreneurship or that of education. The variety of issues to be considered in designing and planning this kind of programme virtually spans the entire scope of educational debates. Some topics such as goals, learning methods, course content, programme organisation, evaluation process (Legendre, 1988) open many debates and rest on some particular basic assumptions, which can often be discussed.

In this first part, some major issues are discussed, and the emphasis is placed upon key questions and their implications on entrepreneurship education programme (Figure 1).

Figure 1 Entrepreneurship education issues

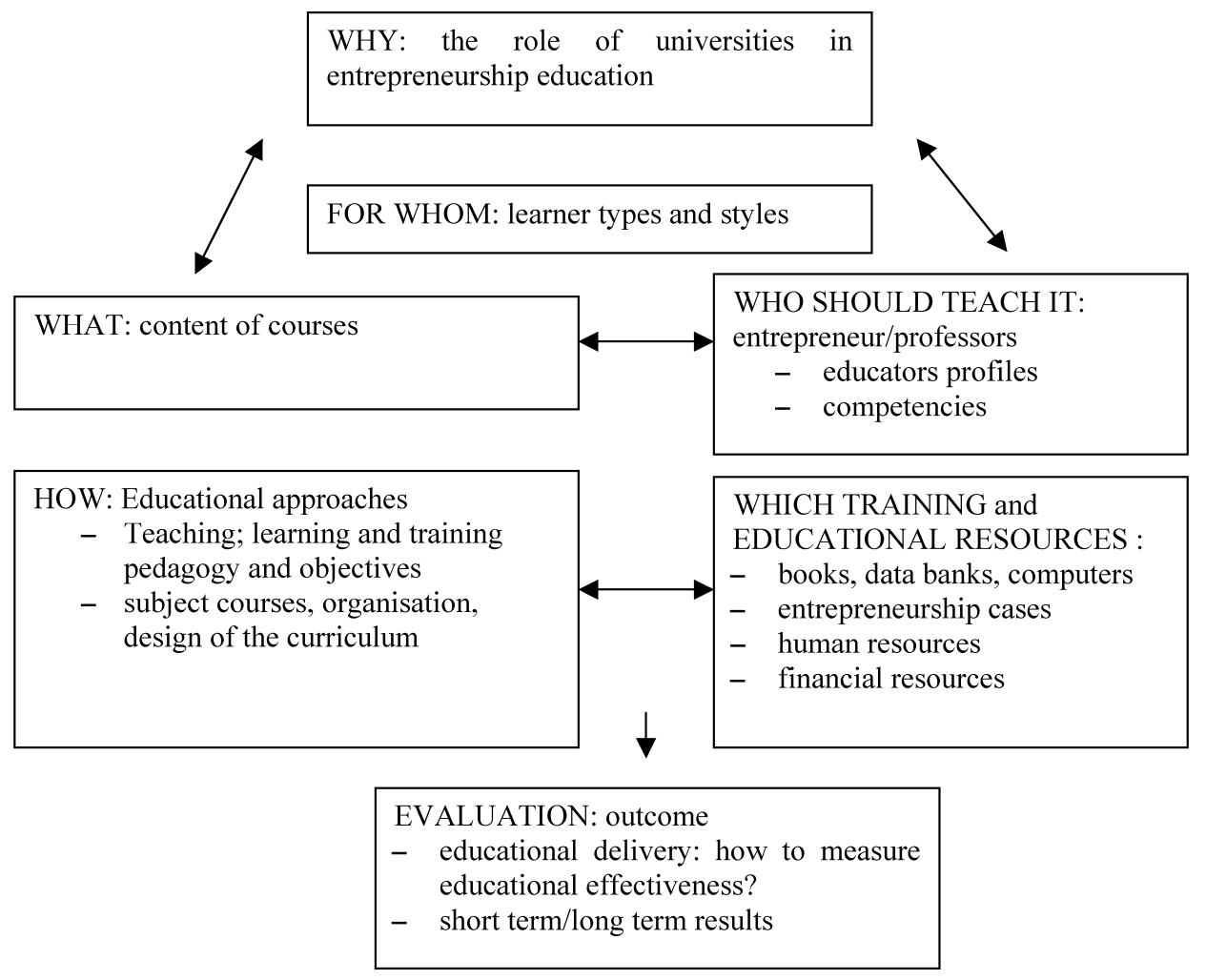




\subsection{Major questioning}

For twenty years, despite the spectacular development of entrepreneurship programmes in higher education around the world (Vesper, 1985; Ziethaml and Rice, 1985; Chusimir, 1988; Dana, 1992), important issues and major challenges have revolved around a key interrogation: to what extent can any form of education enhance the entrepreneurial process?

Two theoretical fields can be solicited for answering such a question: on one hand, entrepreneurship, a young and unstabilised discipline (Gartner, 1990, 1988; Hofer and Bygrave, 1991), and on the other hand educational sciences, where several debates occur about programme design and implementation. Bygrave (1989a) notes that research about entrepreneurship is in its early stages. Major topics such as definitions of entrepreneurship, of the entrepreneurial process or of the entrepreneur are involved in this. Many entrepreneurship researchers argue that the field lacks sufficient frameworks and insist on pursuing causality more aggressively (Bull and Willard, 1993). Moreover, despite the general recognition of the growth and acceptance of entrepreneurship education, research studies have only begun to generate new knowledge and to seek confirmation of its validity (Hills and Morris, 1998b).

We do not wish to open this secular debate about definitional issues and we suggest focusing on the key questions mentioned above. Therefore, we follow Bygrave (1997), Scott et al. (1998) and Fayolle (1999) in arguing that starting new ventures is not natural; there is no 'typical' entrepreneur (Low and Mac Millan, 1988). It requires some knowledge, capabilities, expertise: for instance, present know-how and confidence in one's ability to obtain know-how, abilities and attitudes needed in the future. The entrepreneurship research literature has demonstrated that entrepreneurs with a good general education tend on the whole to be noticeably more successful than those with less favourable education, and even more successful when general education is combined with experience (Vesper, 1990; Robinson and Sexton, 1994). Nevertheless, consensus is still lacking on what entrepreneurship education training (EET) should consist of. The relative newness of the concept justifies that research still has to address the issue, in order to advance entrepreneurship education.

\subsection{What and how should entrepreneurship be taught?}

Several writers in the field of entrepreneurship acknowledge that there is no perfect content, syllabus or programme and that knowledge, competencies and attitudes depend on students' learning needs. The divergent views reflected by the dominant entrepreneurship education models are the result of a growing, evolving field, still short of maturation (Hills and Morris, 1998a, 1998b). An increasing number of researchers recognise and promote the entrepreneurship education and training (EET), because the skills of entrepreneurship and business management can be taught. Nevertheless, some of them argue that these needs cannot be expressed in a school context.

Gibb (1988) also asserts the opposite concept. He considers 'knowing what' and identifies useful tasks and contents for satisfying the learning needs of the future entrepreneur. The focus of much of his work is directed towards identifying the learning contents according to the six stages (steps/levels) of the entrepreneurial process, which reflect the dynamics of venture creation. 
Johannisson (1991) points out a different position, by indicating there may be limits to entrepreneurial training. There may be special qualities displayed by some unusually successful entrepreneurs which cannot be transmitted to others. Moreover, his studies explore other avenues. He concludes that five kinds of knowledge exist. He makes several observations based on in-depth interviews that were conducted with entrepreneurs to attempt to determine their daily activities. He reports that entrepreneurs devote energy to building vision and action (to visioning and acting) rather than elaborating plans and budget.

Moreover, there has been much experimentation with various methods and programmes, which point out important pedagogical issues. Should EET be taught at a late stage to final year students? Should it run throughout the education process infusing the curricula? Should entrepreneurship be taught as a discipline or should it be integrated into other courses? Should methods of teaching enterprise and entrepreneurship adopt or adapt those used to teach management students? Does EET need to evolve its own unique methods?

What and how potential entrepreneurs should be taught is a central issue, but there appears to be a lack of consensus. In fact, debates on how to teach entrepreneurship revolve around three points of view.

- The first one deals with the programme structure: expanded programmes around the business plan or the business functions or the emphasis on additional courses.

- The second one concerns pedagogical methods: how does the learning process differ? Is the cognitive effort different? How is formal expertise taught?

According to Ronstadt (1985), it requires specific methods for unstructured context. As for pedagogical methods, entrepreneurship literature often refers to the Kolb model (1976). Moreover numerous teaching objectives can be pursued; they should be responsive to learners' needs and those of the students selected. Ronstadt (1985) particularly insists on the need for objectives concerning creative skills, ambiguity tolerance, deal-making skills, networking skills. Related to these objectives, recent research (Block and Stumpf, 1992; Timmons and Stevenson 1985) encourages an action orientation and discourages overemphasis on planning and analysis.

- The third issue regards who should teach entrepreneurship. As Hills and Morris (1998b) outline, there is an unresolved debate as to whether or not one must be an entrepreneur in order to effectively teach. Some universities have designed experimental programmes wherein academic professors, entrepreneurship educators and entrepreneurs work together. In any event, professors committed to teaching entrepreneurship seem somewhat different from their peers. By working with different pedagogical approaches, they seem more independent in spirit and they are ready to experiment new approaches; they use new learning technologies and non-traditional delivery mechanisms.

These questions regarding entrepreneurship education illustrate the large scope of issues. Despite numerous descriptive papers indicating what is being done for MBA target learners, our understanding of the entrepreneurial phenomenon is currently insufficient, except anecdotally, to answer this range of questions. If there is still much work to be done for our understanding of entrepreneurial training and education, the actual delivery of EET nevertheless requires attention to the course contents, the pedagogy, the use of new learning approaches, the teacher characteristics as well as the students' needs. In 
fact, MBA graduates also demand different pedagogical approaches to enhance their learning of entrepreneurship.

\subsection{University and entrepreneurship programmes}

In the higher education system, a general university education is not enough to increase entrepreneurial supply. The traditional role of higher education is still based on the assumption that it is a career ladder to the corporate sector and the self-employed professions (those entering the medical legal, medical, veterinary, dental fields, and so on). The debate revolves around the most effective forms of EET to be promoted.

Since the late 1980s, entrepreneurship education and training has been a common policy aim in many countries and particularly in French universities. This policy is underpinned by an assumption that anyone can be trained to be an entrepreneur. For Grant, it is a misconception, because the education system in developed countries inhibits the emergence of visionary entrepreneurs, by catering for the needs of the top percentage of corporate enterprises whilst ignoring or marginalising the educational needs of the entrepreneur. Grant questions the role of the education system in teaching skills associated with running large scale companies, rather than smaller businesses which account for over $98 \%$ of the western business firms. He argues that the education programme should rethink the curriculum emphasis on entrepreneurship. Recent empirical research has made clear that real differences exist between mature organisations and early-life cycle stage firms, which require different management practices, with more attention to cross-functional integration.

We consider that entrepreneurship and small businesses education are interrelated in some extent, and that entrepreneurship education in the 21 st century has to take account of the small and medium enterprises.

\subsection{What conceptual model: teaching/learning models and objectives}

For developing entrepreneurship educational programming, a conceptual model has to be built. Despite greatly increased attention to entrepreneurship education, much of the writing has focused on individual programmes, compilations of course syllabi and experience-based observations. Today, the issue is how it can best be taught. Much of the recent research addresses specific teaching and learning objectives as well as course content and other educational delivery issues (Ronstadt, 1985; Vesper, 1982; Vesper, 1985; Sexton and Bowman, 1986; Hills and Morris, 1998b). According to Hills and Morris (1998b), different emerging models for an entrepreneurship programme exist: each reflects a conceptual view of entrepreneurship education, combined with the reality of previously existing courses, faculty teaching interests and the level of faculty and administrative support for entrepreneurship: the first model focuses on introductory courses in entrepreneurship; the second emerging model is reflective of the stages of the business life cycle.

In 1995, in the face of the paucity of conceptual models to address such issues, we preferred to experiment a new training and learning approach. This paper describes this empirical case study, which relates to this specific experience in the Business and Management Institute of the University in Nantes (France). This entrepreneurship educational programme focuses on independent venture creation: intern projects with entrepreneurs and student work teams are carried out in a flexible manner. 
The educational dimensions of this initiative are especially investigated; they demonstrate the range of problems which educating entrepreneurs must address.

\subsection{Our experience: a model for an entrepreneurship programme}

In the light of our conviction and questioning and after this brief review of entrepreneurship training and education research, the fact remains that entrepreneurship is a young academic discipline (Bygrave 1989a, 1989b); although a body of knowledge has steadily built up over the last 20 years, it is still difficult to design and to implement programmes of graduate entrepreneurial education. This discussion points out there are no 'easy answers' because many factors and components interact. Moreover, the concepts and processes involved in entrepreneurship education should be considered to be just as important as in other disciplines.

It requires pragmatic answers by experiment and evaluating the emphasis of new business education curricula on the processes of entrepreneurship. For about two years, we have adopted this position by experiment specific entrepreneurship courses in a business education curriculum. On the basis of the results achieved, we have now been able to provide a pragmatic template for restructuring the business school curriculum.

\section{General background: history and development of the programme}

This programme is offered in the context of a master's degree course for full-time university students. First we will describe the reasons that led us to introduce this programme by explaining the initial choices and their evolution.

Initially, we wanted to keep up with the changing educational needs reflected by small enterprise dominance. It seemed important to us to have graduates entering business, as a large number of small business owners and entrepreneurs are to be found in developed countries. Initially, the first business school's curriculum was devoted to small enterprises and only based on courses around business functions (finance, accounting and tax, marketing, strategy, human resources, etc.) with standard pedagogical approaches (lecture, case studies, etc.). After two years, we decided to rethink this emphasis on entrepreneurship in this business school's curriculum. We were asked to identify what we perceived to be shortfalls in this education of business school graduates. At the same time, we refused to treat entrepreneurship on a par level with other studies such as finance, marketing, human resources and law, etc.

One of the most prevalent results was that the graduate curriculum focused on teaching functional studies: as Mintzberg (1994) outlined, this business school curriculum emphasis was outdated. Moreover, teaching materials and case studies tended to be based on large company experience and models, there was little experience of small business.

In 1997, the new programme of graduate entrepreneurial education was introduced and based on several new principles: establishing a common core of knowledge for all the students; each student would be equipped with the basic knowledge regarding the academic disciplines associated with entrepreneurship. In addition, specific courses were implemented, around the business plan, market feasibility analysis, the management of innovation, team building, new product development, and pre-venture planning. 
After completing the core courses, the student could decide to take coaching courses covering the processes of entrepreneurial finance, marketing, strategy, etc.

\subsection{What gave birth to the project? Initial goals ... and their evolution}

Such an experience involved explicitly recognising the realities of the university which we were part of. Explicit consideration of university role (educational role), priorities and constraints was essential to subsequent entrepreneurship education implementation. In our university, the role, audiences, objectives and resource priorities have to be taken into account for developing entrepreneurship education efforts.

The second programme was initiated at the University of Nantes (France) in 1997 at the time of the launch of the new MBA curriculum. It sought to address the challenge of encouraging entrepreneurship education in universities, through establishing an original approach by creating a supportive teaching environment for venturing specific start-ups. We decided to introduce change in the management curricula of our MBA: therefore, a pilot project was set up by the Business Administration Institute. At the root of this experimentation was a concern that entrepreneurial qualities of innovation, drive, opportunism and creativity needed an equally creative approach to deliver them effectively. In those days, such experimentation probably appeared dangerous and chaotic: as Hills and Morris (1998) argue, entrepreneurship is rather the antithesis of management education based on teaching the traditional functions of accountancy, marketing, human resources management, etc., and it may lead to the dismantling of the functional bias in teaching in the MBA.

\subsection{The learning objectives: learner types, MBA students}

As potential students varied greatly in this entrepreneurship programme, we decided to mix business and non-business students rather than introducing students' segmentation. Every year, we examined their background, i.e. their level of previous business education and experience, in order to recruit students with different needs. We did not intend to train the students to become entrepreneurs immediately. The learning objectives depended on the students: some of them sought to start a business some day, others to satisfy intellectual curiosity or to consider a possible career alternative. Yet others anticipated supporting entrepreneurs as budding bankers, as financial planners, consultants. Because of this learner diversity, we deliberately have endeavoured to combine different learning styles and methods. According to his or her previous background, each student could design his own programme, after evaluating information source and knowledge that could later be helpful in carrying out his or her entrepreneurial project.

\section{Design of the programme: structure, content, process and timing}

The achievements in the first years and the lessons learned became the basis for further modifications of the programme in subsequent years. Since 1997, the programme has been changed: the new aims were based on several principles: working with entrepreneurs, presenting students with several project ideas, developing links with local economy units (such as business incubators) in order to contribute to and to take part in 
new businesses in the local economy. We decided to give preference to a work context based on a realistic environment. Therefore, the four previous core courses were augmented by an additional, cross-functional course, underlying new educating dimensions such as proactiveness, innovation (Covin and Slevin, 1989; Morris and Paul, 1987) required for business creation (Figure 2).

Figure 2 Programme organisation

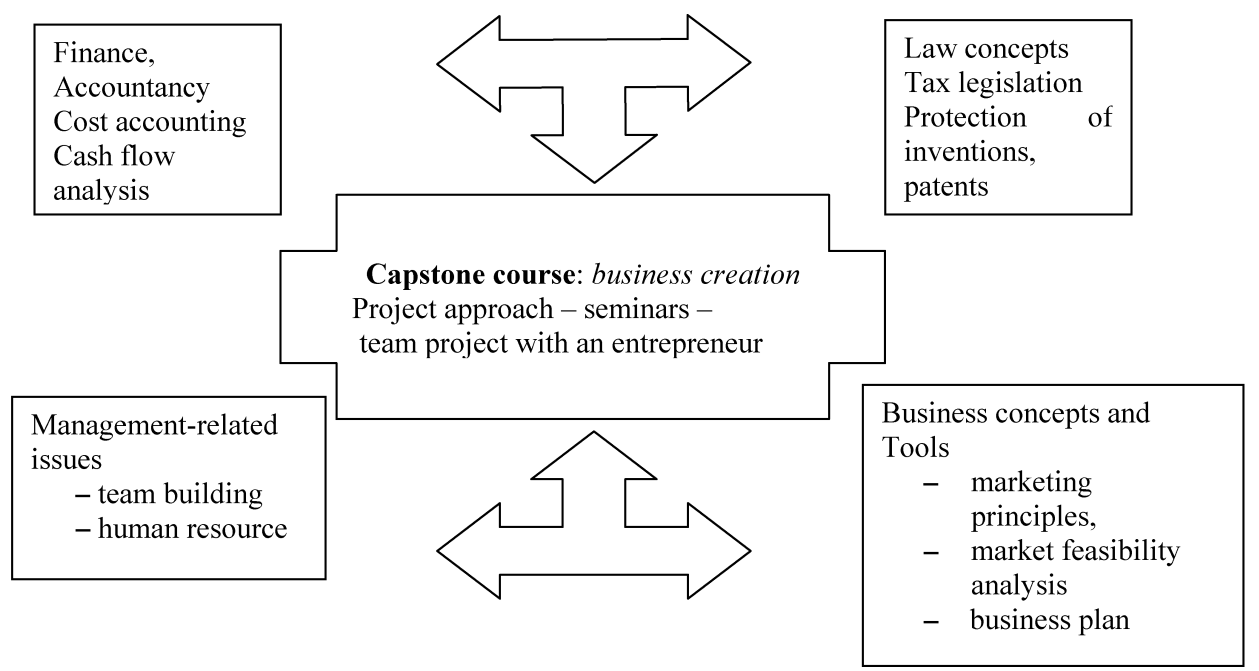

\subsection{The capstone course: an experiential course}

The programme articulation model is also based on a capstone course. This entrepreneurship capstone course is a legitimate substitute for the classical courses. Besides it provides experiential integration of the four core curriculum. After several years of experimentation, we have in fact identified some factors which enhance the probability of an entrepreneurship course's success. We have discovered that some specific choices could better focus the entrepreneurial team's work on improving its processes of successfully fulfilling its original training objectives. Our students select projects they wish to carry out with real entrepreneurs. The training process itself includes seminars and the set of courses required to analyse an opportunity, define a business concept, assess the necessary resources, and build a business plan covering three years of activities.

Regarding pedagogy, this capstone course is based on an unstructured and action-oriented experience approach to teaching as Sexton and Bowman (1986) and Ronstadt (1985) have proposed. The purpose of 'this capstone course' is to provide the students with a business overview through integration of the materials they are supposed to have learned from the core curriculum. It should be noted that this curriculum is built upon four foundation courses such as business tools and concept, finance and accountancy, law, management-related issues. These core courses emphasise functional disciplines, e.g. finance, marketing principles, human resource, management and business tools (Figure 2), whereas this 'capstone' course can be defined as an entrepreneurial experiential course rounding out the whole curriculum. 
After recruiting students, we pre-select projects - business ideas - covering early stage of business growth, particularly from start-up to new venture creation. The selection focuses independent venture creation. In this experiential course, each student has to choose a project and also become a team participant. Each team creatively evaluates types of information sources and contacts that could later be helpful in starting the enterprise.

\subsection{Students' profiles}

Since its creation, the course has been built on two complementary dimensions: the first one deals with the diversity of skills and competencies of the students; the second one concerns the training of people interested in venture creation. Most students are from business, social science or engineering backgrounds. We select motivated students who wish to follow business training through business idea venture. Their motivations for becoming or working with entrepreneurs are likely to vary greatly. We do not encourage them to immediately start their own businesses, because the programme is targeted at students who have limited or no experience of the world of work.

These future graduate students have recently acquired skills and knowledge which may be technical and specialist. This situation provides the opportunity for introducing a curriculum about the creation and development of fast growing businesses, in particular ideas about new products and processes in data processing, biotechnology, life sciences, etc. As Vesper (1990) pointed out, the most successful businesses tend to be those that combine education and experience, insofar as this experientially oriented approach can also offer the students a year long training programme to bridge into the business community through regular meetings with their entrepreneur and the business incubator.

The programme structure involves all graduate students; it consists of three phases (stages), as follows (Figure 3):

Figure 3 A three-stage approach: characteristics

First phase: two months

Third phase: six months
- Foundation course

- initial Seminar session

- Team building

- Project choice

- Business venture design

- Feasibility studies

- Work with start-up entrepreneurs

- Help of counsellors

- Tutorship

- Business Plan

- Expose BP to external panels

- Long-term professional experience 


\subsubsection{The first phase}

The first phase is devoted to foundation courses, concepts acquisition, team building, and project choice. Intensive training is given over a two-month period, on functional management and technical business tools, which students do apply to their business idea. During this stage, problems concerning the business idea are explored, information is collected and students are formed into small action learning sets of four or five (work team). They can also devise ways of overcoming problems and decide on future actions. With the help of four teachers, they develop an action plan and they receive feedback on the results of the actions taken. Traditional forms of support and assistance for setting up in business are proposed. They can be counselled by enterprise advisers (counsellors), bank managers, and accountants. Moreover, students can receive financial, strategy and marketing assistance from teachers. Nevertheless, the process of encouraging independence, autonomy and networking is a continuing theme of the programme. This is followed by the business venture creation phase, where students' team work on building the new business.

\subsubsection{The second phase}

In this second phase, we try to combine both academic and practitioner perspectives over a five-month period of counselling and tutorship. By regularly working with their start-up entrepreneurs, the students experience a qualitative immersion. Moreover, they have to launch different feasibility studies in order to analyse business viability and to validate the business idea; they have to identify the resources and to define how to get into business. This phased approach provides training and support awareness pre-start and start-up stages of the business life cycle. As non-business and business students are selected to attend this programme each year, all attendees can share their knowledge regarding the business idea (chosen project) and learn from each other.

The whole team works on the key issues of a typical early stage, high growth potential venture. By regularly meeting their entrepreneurs, they have a realistic approach of key issues such as business competition, entering a new market, marketing a new product, recruiting, and so forth.

Students have to work and analyse the business activity sector and its external influences, they understand the relationship with the venture's customers, competitors, suppliers, unions, various governmental bodies. They assist the entrepreneur in developing credibility. During this formative period, we always provide advice, and assistance. Nevertheless, each team is capable of making decisions and setting its own goals with its entrepreneur. This phase considerably enhances competence in team management and team building skills.

\subsubsection{The third phase}

In the third phase, we introduce role playing with business plan presentations to internal and external panels. This is intended to validate the business idea. It enables them to experience in a realistic setting how their business plan is assessed by outside people on different key criteria: likely market, originality, market positioning, growth potential, the scale of finance required and availability of resources. In fact, students present their business plan to venture capitalists, and bankers. They then take part in a long-term professional experience (four to six months) with the entrepreneur or the business 
incubator if possible. Moreover, we encourage each project team to take part in a national business creation competition, where they have to present their business plan to financial experts. They can be rewarded and obtain venture financing. Some teachers or counsellors can support students during this initial period of business development.

\subsection{From idea to business plan}

In this phased training approach, managerial and entrepreneurial skills are developed using different learning styles and environment advocated by Gibb (1987). The process is learning by doing, problem solving and grasping opportunities. The success enhancement factors are presented below.

In the first phase, a variety of guest speakers with professional experience contribute to the course. At the beginning of the programme, work and seminars sessions are proposed, where entrepreneurs and professionals from business incubators present their business ideas; they are discussed then selected. Students analyse business scenarios and gain insight into what investors may look for in a business proposal. These entrepreneurs and professionals particularly provide accessible role models and support. Several workshops are held bringing together students, entrepreneurs and teachers. By the end of the workshop, each team has defined its next goals and the work plan.

In the second phase, the stages of validating the idea and preparing a complete business plan are introduced. The students have to keep a diary of their venture's study activities, particularly: how do they look for information sources and assistance? how do they organise the team work? which problems do they have to overcome? They also discover the limits of traditional business tools designed for large companies; they can discover the limits of simplistic approaches to market segmentation which ignore market dynamics concerning emergent product or service. Therefore, they have to develop creative ways to enter the market. They design and analyse different business scenarios after studying business viability (i.e. profitability and cash flow). They use a framework for assessing themselves as potential business owners. This phase is based on the process of initiating students into learning by doing, using team work, brainstorming techniques with their entrepreneurs, and networking. The process of encouraging the team's independence is begun and continued throughout the programme. While the students apply the business concepts to their idea with the help of teachers and professionals, reinforcing concepts such as the importance of effective communication, market analysis or networking are discovered. Several exchanges with professionals are helpful and interesting, given the students' lack of experience in the business environment; it encourages them to network and search for useful contacts. For instance, bank officers take the sessions on business viability and financing the business. During this phase, teachers take the role of facilitators and coaches; peer team knowledge exchanges and cooperative interaction are developed.

\section{Why a real world project driven approach?}

In setting up this programme in 1995 , the dominant constraints were perceived to be institutional. On one hand, the programme was designed to weaken these institutional barriers, and on the other hand, we wanted to demonstrate the relevant positioning of this 
programme in order to convince professional partners, such as business incubator, bankers, and counsellors.

Initially, we recognised the need to overcome the limitations of traditional management teaching and the need for a diversity of methods, i.e. new teaching methods for developing student commitment and interaction. We wanted to introduce more holistic approaches to management training, more emphasis on leading the whole team. Today most teachers do recognise the holistic nature of this new entrepreneurship programme. We observe that the capstone course reveals new skills and offers an integrate pedagogy emphasising the importance of tools and processes required by a recent graduate, who wants to be employed in a small and emerging business. Encouraging practical experience seems necessary to us to enable entrepreneurial qualities to operate in the real business environment. Furthermore, this approach that typically requires group projects might be more entrepreneurially successful. The critical roles of experimentation and failure as vehicles for learning what works, and why, seem very valuable.

\subsection{Evaluation: what lessons have we learnt?}

Some difficulties exist to evaluate whether we have achieved the initial educational objectives. In fact, determining the causal impact of this entrepreneurship programme does at least require the use of control groups without entrepreneurship education, and the use of pre-tests prior to entrepreneurship programme and post-tests immediately after. Nevertheless, since 1997, we have surveyed our students in order to measure their satisfaction and to evaluate their entrepreneurship knowledge and competence enhancing and their business functional knowledge. Graduates frequently comment on how much they have enjoyed the learning process. Some positive effects are highlighted by this experience. These impacts can be summarised on three levels:

- The most important statement is the team's sensitivity to satisfying the needs of the entrepreneur and the venture's constituents; the venture teams have collaboratively blended their capabilities and their skills. Beside commitments to educating programme are consistently bettered.

- The development of mechanisms for successfully integrating an entrepreneurial orientation throughout the whole educational curriculum and based on a concrete entrepreneurial experience allows new relationships and networking.

- The project approach appears to be a very effective pedagogical tool for transferring an entrepreneurial orientation to these future professionals. In this experience, education is less a process of indoctrination than a coaching process; the teachers and educators focus on developing not only the student's mastery of concepts but also the students themselves. Action learning appears as a continuous and circular process of educating which depends on students, teachers, entrepreneurs and counsellors. 
Table 1 Evaluating results based on initial educating goals

\begin{tabular}{ll}
\hline Interests and strengths \\
\hline First phase & $\begin{array}{l}\text { Stimulate students' interest in entrepreneurship by developing real projects and } \\
\text { working on entrepreneurs' ideas, they are seeking to develop }\end{array}$ \\
& High level of coordination between educators, students and entrepreneurs \\
Second phase & $\begin{array}{l}\text { Develop the ability to generate new ideas, recognise opportunities } \\
\text { Increase awareness and understanding of the process involved in initiating and } \\
\text { managing a new business enterprise }\end{array}$ \\
& $\begin{array}{l}\text { Work with real entrepreneurs } \\
\text { Address a variety of issues related to educational delivery, by taking into } \\
\text { account different learning needs; provide support tailored to meet the needs of } \\
\text { graduates } \\
\text { Experiential and active learning with a mixture of team and individual work }\end{array}$ \\
& $\begin{array}{l}\text { Develop a fuller understanding of the interrelationships between the business } \\
\text { functional areas }\end{array}$ \\
& Learn how to apply tools concepts and methods to entrepreneurial situations \\
& Reinforce the confidence in their own ability to start a business
\end{tabular}

Yet there are major challenges for measuring educational effectiveness. Priority is on measuring shorter term results, regarding student satisfaction. Then, we tried to develop measures to capture the results by using Johannisson's taxonomy approach (1991): firstly evaluating the causal impact of the programme on student profiles and capabilities (knowledge, abilities), and secondly, examining the impact of entrepreneurship programme on students' thinking and attitudes towards entrepreneurial activity, business-start-ups.

During these six months, entrepreneurial skills' development is continued and students' experience and learn the value of working in groups. They gain independence and learn to assess the viability of their proposals.

In addition, students have a realistic attitude in all their dealings rather than one of invincibility. Our graduating students with entrepreneurship courses on their record are often valued by recruiters. This programme shortens the time necessary to learn the essentials of venturing and operating a successful business.

The strengths and interests of such a pilot experiment, after experience-based observations and students surveys, can be summarised in Table 2.

Table 2 Some positive impacts of the programme

\begin{tabular}{lll}
\hline Impact & & \\
\hline & $\begin{array}{l}\text { Students' profiles and } \\
\text { capabilities }\end{array}$ & $\begin{array}{l}\text { Students' thinking and } \\
\text { attitudes towards } \\
\text { entrepreneurial activity }\end{array}$ \\
\hline Student satisfaction & $\begin{array}{l}\text { Developing positive self } \\
\text { concept, personal } \\
\text { development; Tenacity }\end{array}$ & $\begin{array}{l}\text { Nurturing positive attitudes } \\
\text { towards entrepreneurial } \\
\text { activity } \\
\text { Adaptability }\end{array}$ \\
& $\begin{array}{l}\text { Ability to rapidly respond to } \\
\text { change in project definition } \\
\text { and building }\end{array}$ & $\begin{array}{l}\text { Working on applied problems } \\
\text { (situations) }\end{array}$ \\
\hline
\end{tabular}


Table 2 Some positive impacts of the programme (continued)

\begin{tabular}{|c|c|c|}
\hline \multicolumn{3}{|l|}{ Impact } \\
\hline Student satisfaction & $\begin{array}{l}\text { Students' profiles and } \\
\text { capabilities }\end{array}$ & $\begin{array}{l}\text { Students' thinking and attitudes } \\
\text { towards entrepreneurial } \\
\text { activity }\end{array}$ \\
\hline $\begin{array}{l}\text { Developing student } \\
\text { interaction and participation }\end{array}$ & $\begin{array}{l}\text { Facilitating acquisition of a } \\
\text { creative and proactive } \\
\text { interdisciplinary } \\
\text { problem-solving mind-set }\end{array}$ & $\begin{array}{l}\text { Developing cross-functional } \\
\text { approach to entrepreneurial } \\
\text { activity }\end{array}$ \\
\hline $\begin{array}{l}\text { Creativity and innovative } \\
\text { practices }\end{array}$ & $\begin{array}{l}\text { Being able to use unstructured } \\
\text { approaches }\end{array}$ & Developing group support \\
\hline $\begin{array}{l}\text { Interaction with } \\
\text { entrepreneurs }\end{array}$ & $\begin{array}{l}\text { Developing new forms of } \\
\text { communication; communication } \\
\text { skills }\end{array}$ & $\begin{array}{l}\text { Emulating the entrepreneurial } \\
\text { management style }\end{array}$ \\
\hline $\begin{array}{l}\text { Developing close contacts } \\
\text { with professionals; creating } \\
\text { a network }\end{array}$ & $\begin{array}{l}\text { Mentoring: the competencies of } \\
\text { others are sought out and utilised }\end{array}$ & $\begin{array}{l}\text { Problem definition rather than } \\
\text { problem resolution: new } \\
\text { problems are defined as they } \\
\text { arise and have to be effectively } \\
\text { prioritised }\end{array}$ \\
\hline $\begin{array}{l}\text { Learning effective } \\
\text { communication with } \\
\text { experts }\end{array}$ & Building networks & $\begin{array}{l}\text { Guidance and support to launch } \\
\text { a venture }\end{array}$ \\
\hline Regular feedback & $\begin{array}{l}\text { Ability development; Higher } \\
\text { technical business skills }\end{array}$ & $\begin{array}{l}\text { A structured approach to } \\
\text { setting up a business }\end{array}$ \\
\hline
\end{tabular}

\section{Conclusion}

This graduate entrepreneurship programme is an innovative and experimental approach to training for the development of entrepreneurship and small business education in a French University. For about ten years, it has provided a direct and concrete experience in venturing a business for students. In the light of this experience, the empirical evidence makes it clear that important new knowledge and capabilities are being developed on specific features of early-life cycle stage firms. In our opinion, such an experimental programme represents the antithesis of the functionalist educating perspective. It allows the implementation of a cross-disciplinary area of training, which drives students to adopt an integrative and holistic approach for business venture creation and development. This programme plays a critical role in instilling new ways for small business education, based on more practice and an orientation towards action in educators and students alike.

Although it can be argued than these recent graduates do not go directly into business creation and self-employment due to their lack of experience, it does help some to launch their own ventures immediately or later, whilst others have gained relevant knowledge and skills to enter a small business enterprise or to work with SME (small and medium enterprise) as counsellors, bankers, and so on.

This articulation of theoretical questions plus the gathering and interpretation of empirical experience can further enrich the understanding of entrepreneurship education design. Nevertheless, if this contribution proposes some new combinations of teaching/learning practices, future research efforts have to be pursued in the entrepreneurship education field about comprehensive evaluation. In these conditions, 
the teaching of entrepreneurship-related topics would also expand and improve as the frontiers of knowledge are pushed forward by research.

\section{References}

Block, Z. and Stumpf, S.A. (1992) 'Entrepreneurship education research: experience and challenge', in Sexton, D.L. and Kasarda, J.D. (Eds.): The State of the Art of Entrepreneurship, PWS-Kent, Boston, pp.17-42.

Bull, I. and Willard, G. (1993) 'Towards a theory of entrepreneurship', Journal of Business Venturing, Vol. 8, No. 3, pp.183-195.

Bygrave, W.D. (1989a) 'The entrepreneurship paradigm (I et II), a philosophical look at its research methodologies', Entrepreneurship Theory and Practice, Fall.

Bygrave, W.D. (1989b) 'The entrepreneurship paradigm (I et II), a philosophical look at its research methodologies', Entrepreneurship Theory and Practice, Fall.

Bygrave, W.D. (1997) 'The entrepreneurial process in Bygrave (dir.)', 2nd ed., The Portable MBA in Entrepreneurship, John Wiley \& Sons.

Chusimir, L.H. (1988) 'Entrepreneurship and MBA degrees: how well do they know each other?' Journal of Small Business Management, July, pp.71-74.

Covin J.G. and Slevin D.P. (1989) 'Strategic management of small firms in hostile and benign environments', Strategic Management Journal, Vol. 10, January, pp.75-87.

Dana, L.P. (1992) 'Entrepreneurial education in Europe', Journal of Education for Business, November-December, pp.74-78.

Fayolle, A. (1999) L'ingénieur entrepreneur français, L'Harmattan.

Gartner, W.B. (1988) 'Who is an entrepreneur? is the wrong question', American Journal of Small Business, Vol. 12, No. 4, pp.11-32.

Garner, W.B. (1990) 'What are we talking about when we talk about entrepreneurship?', Journal of Business Venturing, Vol. 5, pp.15-28.

Gibb, A.A. (1987) 'Enterprise culture - its meaning and implications for education and training', Journal of European Industrial Training, Vol. 11, No. 2.

Gibb, A.A (1988) 'Stimulating new business development', Stimulating Entrepreneurship and New Business Development, Interman, pp.47-60.

Hills, G.E. and Morris, M.H. (1998a) 'The role of entrepreneurship in marketing education', Marketing Education Review, Vol. 2, Summer, pp.1-10.

Hills, G.E. and Morris, M.H. (1998b) 'Entrepreneurship education, a conceptual model and review', in Scott, M.G., Rosa, P. and Klandt, H. (Eds.): Educating Entrepreneurs for Wealth Creation, Ashgate.

Hofer, C.W. and Bygrave, W.D. (1991) 'Theorizing about entrepreneurship', Entrepreneurship Theory and Practice, Vol. 16, No. 2, pp.13-22.

Johannisson, B. (1991) 'University training for entrepreneurship: a Swedish approach', Entrepreneurship and Regional Development, Vol. 3, No. 1, pp.67-82.

Kolb, D.A. (1976) Learning Style Inventory: Technical Manual, Boston, Mc Ber.

Legendre, R. (1988) Dictionnaire actuel de l'éducation, Larousse, p.680.

Low, M.B. and MacMillan, I.C. (1988) 'Entrepreneurship: past research and future challenges', Journal of Management, Vol. 14, No. 2, pp.130-161.

Morris, M.H. and Paul, G.W. (1987) 'Relationship between entrepreneurship and marketing in established firms', Journal of Business Venturing, Vol. 2, No. 3, pp.247-259.

Mintzberg, H. (1994) The Rise and Fall of Strategic Planning, New York Free Press.

Robinson, P.B. and Sexton, E.A. (1994) 'The effect of education and experience on small business and entrepreneurial process', Journal of Business Venturing, Vol. 9, pp.141-156. 
Ronstadt, R. (1985) 'The educational entrepreneurs: a new era of entrepreneurial education is beginning', American Journal of Small Business, Vol. 6, pp.7-23.

Scott, M., Rosa, P. and Klandt, H. (1994) 'Educating entrepreneurs for wealth creation', 4th Internationalizing Entrepreneurship Education and Training Conference, Stirling University, July.

Scott, M.G., Rosa, P. and Klandt, H. (1998) Educating Entrepreneurs for Wealth Creation, Ashgate.

Sexton, D.L. and Bowman, N.B. (1986) 'Evaluative of an innovative approach of teaching entrepreneurship courses', in Roberts, G. (Eds.): Proceedings: Venturing into Entrepreneurship and Small Business, International Council for Small Business.

Timmons, J.A. and Stevenson, H.H. (1985) 'Entrepreneuship education in the 1980s: what entrepreneurs say', in Kao, J. and Stevenson, H. (Eds.): Entrepreneurship: What it is and How to Teach it, Harvard Business School, Cambridge, MA, pp.111-134.

Vesper, K.H. (1982) 'Research on education for entrepreneurship', in Kent, C., Sexton, D. and Vesper, K. (Eds.): Encyclopedia of Entrepreneurship, Prentice Hall, Englewood Cliffs, NJ.

Vesper, K.H. (1985) 'Entrepreneurship: a new direction, or just a new label?', in Kao, J. and Stevenson, H. (Eds.): Entrepreneurship: What it is and How to Teach it, Harvard Business School, Cambridge, MA, pp.62-75.

Vesper, K. (1990) New Venture Strategies, Prentice Hall, Englewood Cliffs.

Zeithaml, C.P. and Rice, G.H. Jr. (1985) 'Entrepreneurship/small business education in American universities', presented at the Annual Meeting of the Academy of Management. 